\title{
A Magyar Királyi Csendőrség és a területvisszacsatolások
}

DOI : 10.31627/RTF.XXIV.2014.39-40-41-42N.119-130P

A Magyar Királyi Csendőrség, tevékenyen részt vett a visszatért területek birtokba vételében. Mint a Magyar Királyi Honvédelmi Minisztériumnak és a Magyar Királyi Belügyminisztériumnak is alárendelt — rendvédelmi testület egyrészt teljesítette a bevonuló honvéd erők tábori rendészeti szolgálatát, másrészt mint közbiztonsági örtestület a visszatért területeken látta el a közbiztonsági szolgálatot. Ezeket a teendőket a terület visszacsatolások ütemében, a feladatoknak megfelelően különböző nagyságú és szervezetű erőkkel hajtották végre. A feladatok végrehajtásához szükséges személyi állományt az egész ország területéről különítették ki.

A visszacsatolt területek térségét hadmüveleti területté nyilvánították. A bevonulástól a polgári közigazgatás müködésének kezdetéig tartották fenn a visszacsatolt területek hadmüveleti területi státuszát. A hadmüveleti területen katonai közigazgatás müködött, ezen időszak alatt épült ki a polgári közigazgatás. A hadműveleti területre az a trianoni határok közötti területről és a visszatért területről a trianoni határok közötti területre polgári lakosság csak külön engedéllyel utazhatott. A magyar határôrizeti szervezetek feladatát alkotta, hogy az érintett trianoni határok hadmüveleti záróvonallá átminősített szakaszát őrizzék és az illetéktelen utazásokat megakadályozzák. ${ }^{1}$

A hadmüveleti területeken — a magyar polgári közigazgatás részeként — folyt a csendőrségi struktúra kiépítése. Ezzel párhuzamosan pedig a testület a haderő tábori rendészeti teendőit is ellátta, valamint a katonai közigazgatás közbiztonsági feladatainak a megvalósításában is részt vett. ${ }^{2}$

Így valósult meg a visszatért területeken a rendvédelmi testületek kiépítése - korabeli szóhasználattal élve — „benépesítése”, amely módosította a Magyar Királyi Csendőrség diszlokációját.

Magyarország fegyverkezési egyenjogúságának az elérése nyomán elhárultak a jogi jellegü korlátok a Magyar Királyi Honvédség fejlesztése előtt. Egyben pedig a Magyar Királyi Csendőrségnél folyó elméleti munka eredményeként a csendőrség szabályzatszerkesztő és tanulmányi bizottsága 1938. VIII. 30-án felterjesztette a Magyar királyi Belügyminisztérium VI-c osztályának „A m.kir. tábori csendőrség szolgálati szabályzata” című szolgálati könyv vázlatát. A csendőrséget tehát nem érte felkészületlenül a terület visszacsatolásokkal kapcsolatban a tábori csendőri szolgálat ellátásának az igénye, bár kétség kívül az elmélet próbakövét alkották a terület visszacsatolásokhoz kapcsolódó tábori csendőri teendők ellátása. ${ }^{3}$

Az 1938. májusában érvényben lévő csendőrségi elhelyezési kimutatás alapján 24 osztály-, 70 szárny-, 181 szakasz- parancsnokság, és 171 őrs, valamint 21 különítmény müködött a Magyar Királyság területén a trianoni határok között. Ez az állapot maradt lényegében az év végéig. ${ }^{4}$

A csendőr testület fedésében müködtek a csendőr kerületenként szervezett lovas alosztályok, amelyek csak névlegesen voltak csendőr alakulatok. A trianoni békediktátum által engedélyezett 35 000 főnyi magyar hadsereg ${ }^{5}$ csapatlovasság alakulatainak, kiképző kereteit — rejtett alakulatként — a Magyar Királyi Belügyminisztérium állományába osztották be. Kezdetben a hét vegyesdandárparancsnoksághoz tartozó szervezetszerü huszár századokat csendőr lovas-alosztályoknak nevezték el. ${ }^{6}$ Harcértékük egy 1938. szeptemberi jelentés szerint 6 tiszt, 190 legénység, 195 ló, 160 puska és 4 golyószóró volt. ${ }^{7}$ A csendőr lovas fedőnevet 1938. október 1-éig használták. ${ }^{8}$

\section{A felvidék déli részének visszatérése}

Az I. Bécs-i döntés nyomán a Felvidéktől visszacsatolt területeken a Magyar Királyi Csendőrségre háruló feladatok eredményes ellátása érdekében 1000 fő csendőrt különítettek ki. Ök 15 századba osztva várták, hogy belépjenek új müködési területükre. 13 századparancsnokot, 4 tisztet, 1 nyomozó csoport-parancsnokot és kereken 1000 csendőrt vezényeltek arra, hogy megalapozzák a jogbiztonságot a visszatért területeken.

Az első örs legénysége Balony községbe települt, amely 3,5 km-re volt Medve községtől ahol honvédség hadihidat vert, ahol 1938. IX. 5-én délután három órakor lépték át a trianoni államhatárt. ${ }^{9}$

Bevonuláskor a Felvidék területét négy zónára osztották fel. Az ütemterv elöírta, hogy naponta mely vonalat érhetik el a csapatok. A cseh hátvédeket a honvédség elővédei négy kilométer távközre követék. A két hadsereg között mindig egy-egy hadikövet (parlamenter) tiszt tartózkodott fehérzászlós gépkocsin.

A magyar alakulatok különböző fegyvernemekből álló oszlopokba soroltak. A menetet biztosított 
formában valósították meg. Az elővéd végére osztották be a csendőrség mellett a rendőrség és a posta különítményeit. A visszatért településeken a községekben csendörség, a városokban pedig a rendőrség vette át a közbiztonsági szolgálat teendőit.

Ha a parlamentertiszt jelentette, hogy a következő községek szabadok, a csendőr- és rendörkülönítményeket gépjárműveken elöre küldték. Így amikor a honvédség alakulatai bevonultak már a csendőrök és a rendőrök látták el szolgálatot. A csehek kivonulásától a csendőrök beérkezéséig a közbiztonsági szolgálatot többnyire a helyi tüzoltók vagy az ideiglenesen megszervezett nemzetőrök látták el. A kezdeti időkben a nagyobb városokban a járőrök mellé egy-egy — a helyi viszonyokat ismerő - nemzetőrt osztottak be. ${ }^{10}$

A csendőralakulatok ereje különböző volt, szakaszba, félszázadba, századba tagozódva meneteltek az elővéddel visszahagyva az átvonult községbe telepítendő őrslétszámot, ahol az új őrs haladéktalanul megkezdte müködését.

A bevonulással kezdetét vette a katonai közigazgatás, mely 1939. I. 5-ével ért véget. Ekkor hozták létre a Felvidék visszacsatolt keleti részéböl, valamint a trianoni határok közötti Magyar Királyság északkeleti területeiből a Magyar Királyi Csendőrség VIII. kerületét, melynek parancsnokságát Kassára telepítették. ${ }^{11}$

A volt határmenti csendőr kerületek területe is átalakult. ${ }^{12}$ A megszállásban résztvevő 13 század 1939. I. 9-ével mint szárnyparancsnokságok kezdték meg müködésüket. ${ }^{13}$

A VIII. honvéd hadtest-parancsnoksággal azonos müködési területtel és székhellyel alakult meg a VIII. csendör kerület-parancsnokság. 1939. I. 23-ával valamennyi hadtest területének beosztása is módosult. ${ }^{14}$ Ez közvetlenül érintette a csendőrséget is, mert a csendőr kerületek területi beosztásának határai pontosan követték a hadtestek illetékességi körzetét.

Felvidéki területek visszacsatolásával a VII. Miskolc-i csendőr kerület határszakaszának jelentős részét átvette a VIII. Kassa-i csendör kerület, míg a VII. Miskolc-i csendőr kerület határa eltolódott az I. Budapest-i csendőr kerület irányába. A I. Budapest-i csendőr kerület egyetlen olyan csendőr kerület lett, amelynek nem volt határszakasza, csak belterülete, mert a Balassagyarmat-i csendőr osztályt a VII. Miskolc-i csendör kerülethez csatolták. Valószínüsíthetö, hogy nem akartak egy rövid határszakasszal rendelkező csendőr kerületet létrehozni.

A változások nyomán 32 osztály-, 86 szárny-, 256 szakasz-parancsnokság és 879 örs állt fel. Gyarapodott a szervezeti egységek száma is, hiszen az osztályok 8-al, a szárnyak 16-al, a szakaszok 75-el, az örsök pedig 123-al növekedtek.

Az átszervezést értékelve megállapítható, hogy az egyes osztályok és szárnyak területét tovább tagolták. 1938. tavaszán a meglévő 70 szárny-parancsnokság közül 26 maradt érintetlen az 1939. februári átszervezést követően. ${ }^{15}$

A részletes elhelyezést vizsgálva kitünik, hogy a korábban felállított különítményeket ôrssé minősítették. Ez azt jelentette, hogy további alkalmazásuk szükséges volt az adott terület közbiztonsága érdekében. ${ }^{16}$

A megnövekedett szakasz-parancsnoki helyeket nem tudták feltölteni, mert az 1938. novemberére tervezett alhadnagyi vizsgát a tiszthelyettesek nem tudták letenni, mert azt a Felvidéki bevonulás miatt elhalasztották. ${ }^{17}$

Az 1938. kiképzési év idejét 6 hónapra csökkentették, mert egyrészt a felvidéki területek visszatérése miatt a csendőrlegénység létszámát 1939. I. 1-vel 1000 próbacsendőrrel gyarapították, másrészt a hadsereg felfejlesztésével a csendőrség létszámát még 400 fővel emelték. Így a létszámemelést megelőzően kiképzésbe betervezett személyi állománnyal együtt összesen 2025 föt kellett kiképezni. Azonban a csendőriskolák (gyakorló tanalakulatok) befogadóképessége mindössze 1094 fö volt. $^{18}$

A Magyar Királyi Csendőrségnek tehát a vizsgált időszak kezdetén jelentősen megnövekedett müködési területen változatlan létszámmal kellett ellátnia feladatait, mivel a pótlásra felvett próbacsendőrök kiképzése ekkor még nem fejeződött be

\section{Kárpátalja visszatérése}

Kárpátalja visszacsatolásában 32 tiszt és 1000 fő csendör legénység vett részt, akik 1939. III. 16-án délután 6 órakor századokba beosztva, felmálházva Csapon várták az indulást. Előtte való napon már beszüntették a tiszti és altiszti továbbképzéseket.

A bevonulást követően az őrshálózat azonnal kiépült. 19 szakasz parancsnokság, és 72 gyalogos örs létesült. ${ }^{19}$

A visszacsatolás kezdetével életbe lépett a „rendszeres katonai közigazgatás”. Ennek rendelték alá 
„Kárpát-csoport” néven a zászlóalj szervezésủ csendőri erőt, amelynek székhelye Ungvárra települt. A század-parancsnokságok Huszt, Munkács, Ilosva helyeken diszlokáltak. Fő feladatuk a Kárpátalján garázdálkodó Szics-gárda felszámolása volt.

A katonai közigazgatás 1939. VII. 7-én megszünt. Így az itt lévő csendőr alakulatok felett a VIII. csendör kerületi parancsnokság vette át az irányítást.

Ezzel egyidőben az ungvári osztály területi beosztása is módosult. Az osztálynak addig alárendelt ungvári és beregszászi szárnyak területe is ennek megfelelően változott. Az újonnan felállt a beregszászi osztály a kárpátaljai területekkel egybeolvadt. Az ungvári 1. és az ungvári 2., valamint a munkácsi szárny-parancsnokság területén csak kisebb változások történtek.

A huszti 9. nyomozó alosztály-parancsnokságot 1939. XI. 1-ével áthelyezték Ungvárra, míg Huszton egy kikülönített nyomozócsoport maradt, melynek parancsnoka KARABÉLYOS Imre cső. fhdgy. lett.

Kárpátalja irányításának céljából létrehozták a „Kárpátaljai Terület Kormányzói Biztosa” tisztséget, aki mellé rendszeresíttetek egy csendőrtiszti beosztást is. E csendőrtiszti beosztást betöltő személy feladatát alkotta a helyi közigazgatás és a csendőrség közötti összhang, együttmüködés megteremtése és ennek fenntartása. 1939. VIII. 1-től dr. KRICSFALUSSY-HRABÁR Endre cső.alez. látta el ezt a feladatot.

A csendőrség szakszolgálati ágai közül a legfontosabb szerepet a híradószolgálat megszervezése és fenntartása képezte. A csendőrségi rádióadó állomások már a felvidéki bevonuláskor is bizonyítottak. A rádióállomások 1938. XI. 8. - 1938. XII. 9-e között 412 táviratotforgalmaztak. A tapasztalatok alapján Kárpátalja visszacsatolásánál az összpontosított csendőrségi erőhöz már rádióadóállomásokat is rendeltek. Az általuk továbbított rádiótáviratok száma 1939. III. 15. - 1939. VI. 26a között 2989 távirat volt. ${ }^{20}$

A visszatért kárpátaljai területek közbiztonsági feladataiból a Magyar Királyi Csendőrségre háruló teendők eredményes ellátásának érdekében a testület személyi állományából újabb létszámkontingenst jelöltek ki. Ezért néhány átmeneti intézkedést kellett bevezetni, amelyek lehetővé tették, hogy az ismét csökkentett erejü őrsök megfelelhessenek a fokozódó igénybevételeknek. Rövidítették a külső szolgálatok időtartamát, a jelentéktelen tereptárgyakat csak szükségszerüen portyázták, természetesen betartva a Szolgálati Utasítás azon rendelkezését, miszerint havonta egy alkalommal az őrskörlethez tartozó minden tereptárgyat le kellett portyázni. Elöírták, hogy a legénységet minél kevesebb irodai munkával terheljék. ${ }^{21}$

A csendőrség felügyelője „Szemle észrevételek az 1939 évről” címü tájékoztatójában úgy fogalmazott, hogy: „Összegzésként megállapitható, hogy a »Magyar Szent Korona testébe visszatért" Kárpátalján a csendörség közremüködése által rövid idö alatt megszilárdult a rendes állami élet, kiépült a teljes igazságügyi és közigazgatási apparátus, $s$ az a csendöri szervezet is, melynek egy része a belsö területekröl vezényelt idösebb legénységböl, míg másik hányada az iskolákból elvezényelt próbacsendörökböl állott." 22

A létszám átcsoportosítás nem éreztette hatását a Magyar Királyság trianoni határok közötti közbiztonságában. Míg a Felvidék visszacsatolására a felső vezetés válogatott legénységet küldött, addig Kárpátaljára csak annyi eröt adhatott, amit a reális szükségletek feltétlenül megköveteltek, de így is megállták helyüket a testület személyi állományának odavezényelt tagja.

\section{Észak-Partium és Észak-Erdély visszatérése}

E területek visszacsatolásában a Magyar Királyi Csendőrség minden eddiginél nagyobb erővel vett részt, a tábori rendészet teendők ellátásában és a térség „,benépesítésésben” egyaránt. A Fővezérségnél, a hadsereg-parancsnokságoknál és a hadtest-parancsnokságoknál egyaránt csendőr altiszt vezetésével négy fős tábori csendör őrsök müködtek. A személyirányító állomásokra 16 csendőr tisztet és 444 csendőr altisztet osztottak be. A hadtáp csendőr-zászlóaljakhoz és a tábori csendőr szakaszokhoz 56 csendőr tisztet és 320 csendőr altisztet osztottak be. A Magyar Királyi Csendőrség a Magyar Királyi Honvédség számára 72 csendőr tisztet és 764 csendőr altisztet bocsátott a rendelkezésére, a tábori rendészeti szolgálat ellátására és a hadtáp csendőr-zászlóaljak vezetése céljából. ${ }^{23}$ A területek „benépesítéséhez” a belügyminiszter 56 csendőr csapattisztet, 6 csendőr gazdászati tisztet és 2268 csendőr altisztet rendelt ki. ${ }^{24}$

A második bécsi döntés és a „benépesítés” között csak 5 nap állt rendelkezésre. A felállításra kerülő katonai közigazgatás szervezeteit — vasúti- és gépkocsiszállítással, 1940. IX. 4-én — Ungváron, Püspökladányban és Cegléden összpontosították. Itt alakultak meg az egyes parancsnokságok, amelyek továbbirányítását a Fővezérség által a helyszínre kirendelt személyirányító tisztek végezték. 
Hadseregenként felállítottak egy csendőr csoport-parancsnokságot. ${ }^{25}$ A visszacsatolt területekre megvalósítandó bevonulás tervezetében már kijelölték a felállítandó csendőr osztály- és csendőr szárny-parancsnokságok székhelyeit is. ${ }^{26}$

A bevonulás sorrendjében sorrendjében álltak fel a már birtokba vett területeken a csendőrségi szervezeti egységek, összesen 11 osztály-, 22 szárny-, 44 szakasz-parancsnokság és 298 őrs. Ezeken kívül megkezdte müködését 5 nyomozó osztag, 4 híradó őrs és tiszti parancsnokságonként 18 rádióvevő állomás. ${ }^{27}$

A csendőr őrsök első állomáshelyének megállapítása a csendőr osztály-parancsnok feladata volt. Ezek későbbi áthelyezése, megszüntetése, új örsök felállítása a területileg illetékes vármegyei katonai parancsnok véleményének kikérésével valósulhatott meg. Eltérő felfogás esetén a hadseregparancsnok döntött. Ezek a feltételek csak a katonai közigazgatás müködése alatt illették meg a haderő illetékeseit.

A diszlokáció kialakítása során azt az alapelvet követték, hogy az 1918-ban meglévő szárnyparancsnokság székhelyén osztály, a szakasz-parancsnokság székhelyén pedig szárny-parancsnokság létesüljön. Az őrsök száma osztályonként változott. A tagolt hegyi terepviszonyok miatt aránylag kis területủ és csekály számú őrssel rendelkező szárny-, illetve osztály-parancsnokságok létesültek. A Magyar Szent Korona alá visszatért Észak-Partium-i és Észak-.Erdélyi területeken 1918-ban 301 csendör őrs müködött, így ennyit vettek alapul visszacsatolt területeken az új csendőrségi diszlokáció létrehozásakor. Ettől csupán annyiban tértek el, hogy az örsök számát $25 \%$-al növelték. A magyar csendöri erők diszlokációja lényegesen eltért a román csendőrség területi lehelyezkedésétől, mivel egy-egy magyar őrs körlet területén 3-5 román őrs is ténykedett a visszacsatolást megelőzően. A román csendőr legénység azonban nem hivatásos, hanem sorozott állományú volt. ${ }^{28}$

A csendőrségtől vezényelt legénység csak hivatásosokból állt. Létszámuk 2103 föt tett ki, e létszám 48 szakaszparancsnokból, 60 nyomozóból és 1995 főnyi legénységből állt. Ezt létszámot növelték a szakszolgálatosok. A visszacsatolt területek csendőri szervezeteinek gazdasági hivatalait kezdetben a gazdászati tiszte hiánya miatt nem állították fel. Ezért a gazdászat-igazgatást ideiglenesen a hadsereg-csoportoknál lévő személyzet végezte. ${ }^{29}$

A csendőrség és rendőrség működési területe a katonai közigazgatás területén is hagyományosan oszlott meg. A városok területén a rendőrség, míg az ezeken kívül eső területeken a csendőrség teljesített szolgálatot.

A települések városi vagy községi jellege tekintetében az 1918. évi magyar közjogi helyzet volt az irányadó. A román uralom alatt városi rangra emelt településeken a csendőrség teljesített szolgálatot. ${ }^{30}$

Az csendör örsöket ott kellett felállítani, ahol 1918-ban is magyar csendőr örsök müködtek. Ezt az elvet azonban nem vették szigorúan. Ahol a közbiztonsági viszonyok indokolták, vagy a közigazgatási beosztás megváltozott, tovább ha az új határvonal miatt szükségesnek látszott, az egyes csendőr őrsök állomáshelyét és a rendszeresített létszámát az 1913. évitől eltérően állapították meg. A csendőr őrsök számának az 1918. évi állapotokhoz képest történő növelését későbbi időre halasztották, mert az ehhez szükséges létszám még nem állt rendelkezésre.

A belterületi örsökön a portyázó szolgálat ellátását kezdetben csak a községekre, nagyobb lélekszámú lakott helyekre, vasútállomásokra, bánya- és ipartelepekre korlátozták. A határszéli csendör örsök viszont kötelesek voltak az örskörletükhöz tartozó határvonalat is portyázni. ${ }^{31}$

$\mathrm{Az}$ alárendeltséget tekintve a visszacsatolt területeken a katonai közigazgatás ideje alatt szolgálatot ellátó csendőri erők saját elöljáróinak és az illetékes hadsereg-parancsnokság útján a Honvéd Vezérkar főnökének voltak alárendelve. A katonai közigazgatási parancsnokok a müködési területükön felállított alakulatokat közvetlenül, a csendör nyomozó-egységeket és híradó különítményeket az illetékes hadsereg csendör csoport-parancsnokság útján vehették igénybe. ${ }^{32}$

A visszacsatolásban résztvevő három magyar hadseregnél egy-egy csendőr csoport-parancsnokság állt fel. ${ }^{33}$ Ugyanakkor 550 főnyi csendőr legénységet vezényeltek az Észak-Erdély-i örsök megerősítésére. Ez a létszám úgy oszlott meg, hogy az I. magyar hadsereg csendőr csoportparancsnokságának a területére 235 föt, a II. magyar hadsereg csendőr csoport-parancsnokságának a területére 180 föt, a III. magyar hadsereg csendőr csoport-parancsnokságának a területére pedig 55 föt helyeztek, emellett pedig a térség teljes területére kiterjedő hatállyal 80 főnyi csendőr mozgótartalékot hoztak létre. ${ }^{34}$

A csendőrség vezetése többször kérte a Fővezérséget, hogy tehermentesítse a katonai közigazgatás szervezetében müködő állományt e szolgálat alól, mivel a rendes közbiztonsági szolgálat ellátására sem állt rendelkezésre a megfelelő létszám.

1940. október folyamán a III. és a II. hadsereget kivonták Erdély területéről, alakulataikat helyőrségeikbe szállították. Ezzel megszünt a csendőrség három hadsereg szerinti tagozódása. Így az addigi csendőr csoport-parancsnokságok feleslegessé váltak. ${ }^{35}$ A megszüntetett csendőr csoport- 
parancsnokságok közvetlen szervezetei a nyomozó osztagok, híradó őrsök és gazdászati kirendeltségei, azonban továbbra is a helyükön maradtak a területileg illetékes csendör csoport-parancsnokság alárendeltségében.

Az I magyar hadsereg béke-elhelyezési körletét Észak-Erdélyben jelölték ki. Az Észak-Erdélyben diszlokáló I. magyar hadseregnél Hadsereg Csendőr csoport-parancsnokságot szerveztek. Ennek parancsnokává VATTAY Ferenc cső. ezds. nevezték ki, akit az I. magyar hadsereg parancsnokának közvetlenül alárendetek. ${ }^{36}$ Feladata a csendőrség müködésének irányítása a közbiztonsági szolgálat és a kiképzés tekintetében, szakvélemény nyújtása a hadsereg parancsnoknak, aki minden csendőrségi vonatkozású szolgálati, személyi ügyben a katonai közigazgatás vezetője is volt. ${ }^{37}$

Az égetővé vált létszámhiány mind a legénységnél, mind a tisztikarban éreztette hatását. Összesen 6000 próbacsendör kiképzéséröl kellett volna gondoskodni, de ennek nem voltak meg a feltételei. Azok a csendőrtisztek, akik a kiképzőkeretekhez voltak vezényelve, a testület mozgósítása és hadiállományra való kiegészítés során hadibeosztást láttak el. A hadtáp csendőr-zászlóaljaknál 56 fö, a tábori csendőrségnél 16 fö, összesen 72 csendőr tiszt látott el ilyen feladatot. A testület mozgósítása esetén a tanintézetekben a kiképzés általában szünetelt.

Ennek megindításáról a Magyar Királyi Honvédelmi Minisztérium 20.(csendőrségi) osztály véleménye szerint: „Nem jelentkeznének zavarok, ha Erdélyben a közbiztonsági szolgálat a hadtáprendszer keretében történnék. A mostani kettösség azonban messze túlhaladja a csendörség létszámteljesitó képességeinek határait, mert nemcsak a hadtáp alakulatokat kell tiszti és legénységi létszámmal ellátnia, hanem ugyanakkor és ugyanazon a területen a rendes közbiztonsági szervezetet is fel kellett állitania.

Ezt a kettös terhet világosan mutatja a következö szembeállitás: 50 csendörtiszt végzi az egész felszabadult terület közbiztonsági szolgálatát és 56 csendörtiszt van beosztva a hadtápzászlóaljakhoz, tehát több tiszt a kisegitö szolgálatban, mint a hivatásszerü beosztásokban.

Ezért vált elkerülhetetlenné, hogy a folyó évben véglegesitett hadnagyok is szárnyparancsnoki beosztást kapjanak. Ugyanez vonatkozik a hadtápzászlóaljakhoz vezényelt 352 hivatásos csendörre. Eddig a magasabb parancsnokságokhoz és hadtáphoz vezényelt csendörök közül kb. 200 vonult be, visszamaradt tehát 600-700. Ez a létszám egyharmada az egész új területre vezényelt létszámnak. Mivel most Erdélybe újabb 1000 csendört kell vezényelni, a régi területeken a hivatásos és nem ténylegesek aránya már $50 \%$-os lesz." ${ }^{\mathbf{3 8}}$

Ezért fordult elő az, hogy a létszámgondok enyhítésére a csendőrségnek a trianoni határok közötti Magyarország területén állomásozó alakulatai számára a honvédség őrvezető és tizedes rendfokozatú lévő katonákat adott át a testület részére. Vagyis nem tényleges viszonybeli csendőröket osztottak be közbiztonsági szolgálatra. Ezen túl nyugalmazott csendőröket is reaktiváltak.

A katonai vezetés reagált a 20. osztály felterjesztésére, ezért 54 fö csendőr tisztet és csendőr altiszteket a seregtestektől, a hadtáp zászlóaljaktól visszavezényeltek 1940. X. 10-ig eredeti beosztásukba. 1940. XI. 23-án megindult a képzés az 1909-ben alapított Nagyváradi Csendöriskolában, amelynek parancsnokává vitéz nemes battyáni PAKSY-KISS Tibor cső. ezds-t nevezték ki. ${ }^{39}$

A rendes feladatai mellett a testület különleges feladatokat is ellátott. Például a Fővezérség megkeresése alapján útbiztosító és rendfenntartó szolgálatra Kolozsvárra vezényeltek a budapesti és pesterzsébeti gyalog tanalosztályok keretéből 81 fö próbacsendőrt, 8 fő segédoktatót. Az I. csendőr kerület örseiről pedig 31 fö csendőr altisztet dr. ENDRŐDY Barna cső.örgy. parancsnoksága alatt Kolozsvárra vezényeltek a Kormányzó 1940. IX. 13-án történő bevonulását biztosító feladatokban történő részvételre. ${ }^{40}$

A katonai közigazgatás a visszacsatolt erdélyi és pártiumi területeken 1940. XI. 23-án megszünt, ezzel az időponttal nevezték ki az e területeken felállított csendőr alakulatok parancsnokait is. 1940. XI. 24-étől kezdte meg müködését a kolozsvári IX. csendőr kerület-parancsnokság, VATTAY Ferenc cső.ezds. vezetésével. ${ }^{41}$ Ezzel egyidejüleg felállt a X. csendőr kerületi-parancsnokság a székelyföldi vármegyék területén Marosvásárhely székhellyel. Parancsnoka PINTÉR Aladár cső.ezds.-t nevezték ki. ${ }^{42} \mathrm{Az}$ Észak-Erdély-i két csendőrkerület kialakításának az volt az oka, hogy ez a terület egyetlen kerületnek túlságosan nagynak bizonyult és a terület jellege is a két kerület kialakítása mellett szól.

A visszatért területeken az újonnan felállított két csendőr kerületen kívül egy harmadik, a Kassa székhelyü VIII. csendör kerület is osztozott, megkapva a Máramarossziget székhelyü csendôr osztályt és csendőr szárnyat, valamint három szakasz-parancsnokságot, a Felsővisó-i csendőr szárnyparancsnokságot, és alárendeltségében két csendőr szakasz-parancsnokságot, továbbá 16 csendőr örsöt. A Magyar Királyi Honvédség béke diszlokációját pedig úgy alakították ki, hogy Észak-Erdély területén a kolozsvári IX. honvéd hadtest állomásozott. 


\section{Délvidéki területek visszatérése}

A Magyar Királyi Csendőrség erői később csatlakoztak a bevonulásban résztvevő a Magyar Királyi Honvédséghez. A belügyminiszter már 1941. IV. 3-án készültségi szolgálatot rendelt el az I-VIII. csendőr kerület, valamint a Központi Nyomozó Parancsnokság részére a Szolgálati Utasítás 189. pontja alapján. ${ }^{43}$

A bevonuló alakulatok a III. magyar hadsereg kötelékébe tartoztak. A seregtest parancsnokának, GORONDY-NOVÁK Elemér altbgy.-nek ${ }^{44}$ közvetlenül alárendelve müködött a Déli Hadsereg Katonai Közigazgatás Csoportparancsnoksága.

A szükségszerü katonai közigazgatás lépett életbe, mivel nem teljesen békés úton kerültek vissza délvidéki területek Magyarországhoz. A szükségszerü katonai közigazgatásnak alapvetően közbiztonsági vonatkozású feladatai voltak, melyeket a bevonuló csapatok elláttak. Azonban a bevonulás gyors befejezése lehetővé tette a rendszeres katonai közigazgatás rövid időn belül történő bevezetését.

A Délvidékre vezényelt csendőrségi állományt a Déli Hadsereg Csendőr Csoport-Parancsnoksága fogta össze, vitéz HALMY József csö.ezds. ${ }^{45}$ vezetésével.

A csendőrök két nagy részre osztva várták a bevonulást. A Bácskai bevonulásra rendelt erők Kiskőrösön, míg a Bánátba szánt alakulatok Kiskunfélegyházán gyülekeztek.

Az indulási parancsot 1941. IV. 14-én éjszaka adták ki. A Bácskai bevonulásra rendelt erőknek 1941. IV. 15-én Zomborba kellett érkezniük gépkocsin, 1 csendőr tiszttel és 192 csendőr altiszttel ZÁMBORY Árpád cső. alez. parancsnoksága alatt. Belőlük hozták létre a zombori osztályt. Ugyanekkor Szenttamásra gépkocsikon útba indult a leendő újvidéki osztály, vitéz BÁTORY Géza csö. alez. vezetésével 2 csendör tiszttel és 330 fö csendör altiszttel.

A bánáti állomány 1941. IV. 15-én vagonírozott be Kiskunfélegyházán, ők Sáripuszta-Tolvajosra utaztak FARBAKY József csö.alez. irányításával 1 csendör tiszttel és 100 csendőr altiszttel. Ök képezték a leendő nagybecskereki osztály létszámát.

Ugyanoda tartott a pancsovai osztály 388 csendőre és a nagybecskereki osztály fennmaradó 199 fönyi legénysége 5 tiszttel vitéz GERENCSÉR Jenő csö.örgy.-gyal az élen. ${ }^{46}$

Az osztályok beérkezésük után azonnal felvették az érintkezést a helybeli honvéd parancsnokságokkal és megkezdték a rend helyreállítását. A zombori osztály 1941. IV. 15-én délután 6 óra 20 perckor érkezett Zomborra. Az Újvidékre helyezett csendőrség aznap 11 órára Szabadkát, délután 6 órára pedig Szenttamást is érte el. A Szenttamásra érkezők 1 órán belül továbbindultak végleges működési területének birtokbavételére. A nagybecskereki és pancsovai osztályok 1941. IV. 15-én reggel együttes vasúti szállítással indultak útba a Szeged-Horgos vasútvonalon Szabadkára. A menetcélt, menet közben végzett biztosítással és útvonal felderítéssel este 8 órára érték el. ${ }^{47}$

A csendőri vezetés Bánátban két osztály- és hat szárny-parancsnokság, valamint 69 örs létesítését vette tervbe.

A Szabadkán elhelyezett Nagybecskerek-i osztály 4 csendőr tiszttel és 299 fö csendör legénységgel, továbbá a Pancsovai osztály 4 csendőr tiszttel és 388 fö csendőr legénységgel a városban és környékén tisztogató és rendfenntartó feladatot látott el. Ezért a város bejáratánál a Nagybecskerek-i osztály öt helyen örséget állított. A Pancsova-i csendőr osztály eröi pedig a város belterületén harminc csendőr járörrel járőrszolgálatot láttak el.

A Fővezérség utasítására a Nagybecskerek-i csendőr osztály a visszatért déli terület trianoni határvonalán, mint hadmüveleti és gazdasági záróvonalon 9 örsöt telepített 98 fövel. A törzs Bezdánba települt. Feladatuk a meghatározott engedéllyel történő közlekedés biztosítása, a jogosulatlan átlépés és tartózkodás megakadályozása volt. E feladatokat razziázással kellett végrehajtaniuk. A megerősítés azért vált szükségessé, mert a trianoni határon telepített határvadász őrsök — amelyek a volt magyarjugoszláv trianoni határon a hadmüveleti záróvonallal kapcsolatos teendőket látták el - a csempészeket és az engedély nélküli határátlépőket nagy számuk miatt már képtelenek voltak feltartóztatni. A záróvonal átlépésének lehetővé tételét később a közbiztonsági viszonyok akadályozták. ${ }^{48}$

A hadsereg kivonása után a Déli Hadsereg Csendőr Csoport-Parancsnokság a vezérkari főnökség katonai közigazgatási osztálya útján a szállásmester közvetlen alárendeltségébe került.

A bánáti terület benépesítésére szánt katonai közigazgatási szervezetek a bizonytalan helyzetre való tekintettel 1941. V. 4-ig Kiskunfélegyházán maradtak, majd leszerelték. A katonai vezetés a bánáti területre vezénylendő csendőrséget és rendőrséget a közbiztonsági helyzet megszilárdítása végett a délvidéki terület több részén ideiglenesen bevetette. Ezeket az erőket 1941. júliusában fokozatosan leépítették

A Nagybecskereki osztály állományából 3 csendőr tisztet és 229 fő csendőr legénységet vezényeltek vissza az eredeti alakulatukhoz. Így Újvidéken 65 fő csendőr, egyéb helyen pedig 6 fő csendőr 
maradt. A Pancsovai osztálytól 3 csendőr tisztet és 310 fő csendőr legénységet vezényeltek vissza az eredeti alakulatukhoz. Így Újvidéken 30 fö, másutt pedig 48 fö csendőr maradt. ${ }^{49}$

A katonai közigazgatás megszűnésével - 1941. VIII. 15-én éjféltől, míg a Mura folyótól északra eső területen 1941. VIII. 19-én éjféltől — állt fel a végleges csendőri szervezet. ${ }^{50}$

A Szabadkán felállított csendőr szárny-parancsnokságot Bajáról helyezték át. Baján két csendőr szakasz-parancsnokság szünt meg, illetékességi területük pedig beleolvadt a szabadkai szárnyba.

A polgári közigazgatás bevezetésével szünt meg Dárdán a csendőr szárny-parancsnokság, mely ekkor még a baranyai háromszög területét tartotta ellenőrzése alatt. Ezt követően alakult meg újonnan a mohácsi csendőr szárny-parancsnokság.

Ennek felállításával egyidejüleg megváltozott a pécsi csendör osztály területi illetékessége is, amelynek alárendeltségébe lépett a Mohács-i csendőr szárny-parancsnokság. Ez az új csendőr szárny a Drávaszög örseit, valamint a pécsi csendőr szárny nyolc csendőr őrsét foglalta magába. Ez érintette a pécsi csendőr szárnyat nyugatról határoló szigetvári csendőr szárnyat, melynek négy őrsét csatolták a pécsi csendőr szárnyhoz. Így a pécsi csendőr osztály mindhárom szárnya megközelítően azonos számú örsöt irányított, a szigetvári csendőr szárnynak 17, a pécsi csendőr szárnynak 18, míg a mohácsi csendőr szárnynak 15 örse lett.

A Muravidék területén 1941. VIII. 19-ével három csendőr szárny-parancsnokság osztozott, a muraszombati, a zalaegerszegi és a nagykanizsai csendőr szárny-parancsnokságok. A rendezés során a szombathelyi csendőr szárny öt őrsét csatolták a Muraköz csendőr szárny kilenc őrséhez. Ebből alakult meg a Muraszombati csendőr szárny. Az újonnan létrehozott zalaegerszegi csendör szárny örsei a szomszédos keszthelyi csendőr szárny két őrséből, a nagykanizsai csendőr szárny tizenegy őrséből, illetve három muravidéki örsböl álltak össze.

A nagykanizsai csendör szárny beosztása úgy változott, hogy a már fent említett tizenegy csendőr örsöt átadta a zalaegerszegi csendőr szárnynak, egyet pedig átvett a keszthelyi csendör szárnytól, míg muravidéki csendör örsökből 11-et kapott.

A Duna-Tisza közi területek a szegedi V. csendör kerület-parancsnokság, a Baranya háromszög a pécsi IV. csendőr kerület-parancsnokság, míg a Muravidék területe a szombathelyi III. csendőr kerület-parancsnokság alárendeltségébe került.

Ez után a Magyar Királyi Csendőrség diszlokációja nem sokat változott. Új karhatalmi jellegü alakulatok, csendőr századok felállítására, a szakalegységek számának növelésére (közlekedési-, repülőtéri örsök, hiradó alakulatok, nyomozó alosztályok, stb. felállítása) minőségi fejlesztésre, majd a háborús feladatok megvalósíthatósága érdekében létrehozott szervezetmódosításokra került sor.

\section{A tanulmány szövegében alkalmazott rendfokozati röviditések jelölésének oldása:}

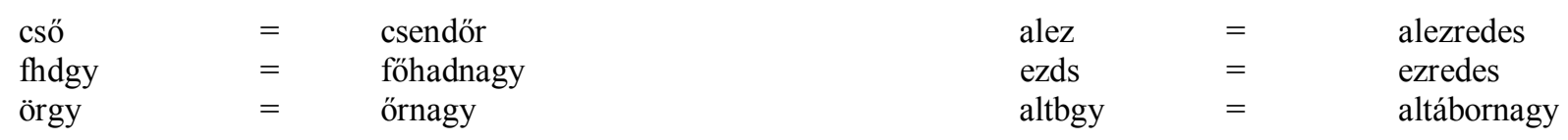

Jegyzetek:

${ }^{1}$ PARÁDI: A magyar állam határörizete 1920-1941. 191-207.p.

${ }^{2}$ PARÁDI: A Magyar Királyi Csendörség. Az elsö magyar polgári, központositott, közbiztonsági örtestület 1881-1945. 102-103.p.

${ }^{3}$ SZAKÁLY: A magyar tábori csendörség története 1938-1945. ; KAISER: A Magyar Királyi Csendörség története a két világháború között. 124.p.

${ }^{4}$ Pontosabban 1938. XI. 1-én ideiglenesen új szárnyparancsnokság létesült Veszprémben, Veszprém 2. elnevezéssel. Az addig ott lévő szárnyparancsnokság Veszprém 1. lett. Ez a módosítás csak a szomszédos adonyi és enyingi szárnyak beosztását érintette.

HIM-HL BM. 1938. 3.020/Res.VI-b.

5 1921/XXXIII.tc.

${ }^{6}$ A Magyar Királyi Csendőrség testületi színei az Osztrák-Magyar Monarchia óta buzérvörös alapon acélzöld volt. ZEIDLER ; OLASZ - PARÁDI - ZEIDLER

Megkülönböztetésként buzérvörös alapon acélzöld színü csendőr hajtókájuk volt, eltérően a búzavirág-kék parolitól és a tábori (BOCSKAI) sapkát is kakastollal viselték.

ADONYI-NÁREDY - NAGY: 74.p.

${ }^{7}$ HIM-HL Vezérkari fönökség iratai 1938.3.263/eln.1.vkf.

${ }^{8}$ A Bled-i egyezményt követően — amelyben a kisantant államok elismerték Magyarország fegyverkezési egyenjogúságát — már nyíltan is a Magyar Királyi Honvédség szervezetéhez tartozhattak.

${ }^{9}$ Magyar Csendőrök a Felvidéken. I.rész.

${ }^{10}$ Magyar Csendörök a Felvidéken. II. és III.rész.

11 A Felvidék visszatérése kapcsán létrehozott — Kassa székhelyü — VIII. csendőr kerület parancsnokai voltak lófő lemhényi GÁBOR Péter (1939.I.5. - 1939.V.1. tartósan vezényelve), lófő lemhényi GÁBor Péter (1939.V.1. - 1940.XI.23.), TÖLGYESY Győző (1940.XI.23. - 1944.X.28.), SÁróY Kálmán (1944.X.28. - 1945.III.31.)

SZAKÁLY: Akik a magyar királyi csendörséget 1919 és 1945 között vezették. Történelmi-statisztikai áttekintés a magyar királyi csendörség felsö vezetöiröl. 121.p. és 277.p. 
${ }^{12}$ Csallóköz területe a II.-, az Ipoly folyó vonalától Rozsnyóig terjedő terület a VII. csendőr kerülethez került. Ezzel párhuzamosan Kassán, Komáromban, Rimaszombaton és Ungváron osztály-parancsokságok álltak fel.

${ }^{13}$ Az osztály-parancsnokság Dunaszerdahely, Érsekújvár, Beregszász, Galánta, Ipolyság, Komárom 1.-2., Kassa, Léva, Losonc, Rimaszombat, Rozsnyó, Ungvár állomáshelyekre települtek.

${ }^{14}$ HIM-HL Hadrendek 60 000/Eln.1.a. 1938.HM.ut.

${ }^{15}$ Változatlanul maradtak Budapest 1., Eger, Győr, Hatvan, Jászberény, Kisvárda, Magyaróvár, Mátészalka, Mezőkövesd, Miskolc, Mohács, Mór, Nagykanizsa, Nagymaros, Pápa, Pécs, Salgótarján, Sarkad, Siklós, Szekszárd, Szentgotthárd, Szerencs, Szigetvár, Szombathely, Tab és Tiszafüred székhelyü szárny-parancsnokságok.

${ }^{16}$ Például megerösítették a bányavidékek körzeteit. A salgótarjáni területen alakult meg a zagyvarónai őrs, amelyet a határ közelsége is indokolt. A dorogi bányáknál a szomori őrs kezdte meg müködését. A hadiipar szempontjából fontos területen alakult meg a Pét-gyártelep-i, valamint az inotai örs. A solymári és lakihegyi, valamint a törökbálinti 2.(gyártelepi) őrsök felállítása a székesfőváros vonzáskörzetének kiemelt jelentőségét bizonyítják. A pilismaróti és a dunaalmási őrsök a volt csehszlovák, míg a nagycserei a román határszakaszon alakultak meg.

${ }^{17}$ HIM-HL. HM. 1939. 80 551/eln.20.

${ }^{18}$ Loc.cit.

${ }^{19}$ Huszton osztály-parancsnokságot, az alárendeltségében pedig 5 szárny-parancsnokságot hoztak létre. A Kárpátalján felállított csendör osztály-, illetve szárny-parancsnokságok székhelyei voltak: Huszt (osztály-parancsnokság) 1. Szárnyparancsnokságok települtek pedig: Husztra 2., Nagybereznára, Nagyszőllősre és Rahóra. Huszton felállt a 9. nyomozó alosztály-parancsnokság is vitéz ÁGHY Zoltán cső.őrgy. vezetésével.

${ }^{20}$ BARTOS

${ }^{21}$ HIM-HL. BM. 1939. 3610/24.sz. Res.VI-b.

${ }^{22}$ HIM.HL. HM. 1940. 74 976/eln.XX.

${ }^{23}$ HIM.HL. Vezérkari fönökség 1941-4221/eln.kat.közig.

${ }^{24}$ Tájékoztató a katonai közigazgatás müködéséröl a felszabadult keleti és erdélyi részeken.

${ }^{25}$ Az előkészített csendőr erők csoportosítása a következő volt: Ungváron, a Beszterce-Naszód-, Csík- és Máramaros vármegyébe vezényelt 3. hadsereg csendőr csoport-parancsnokságának az erőit koncentrálták. Szolnokon, a Háromszék-, Kisküküllö-, Kolozs-, Maros-, Torda-Nagyküküllő-, Szatmár-, Szilágy- Szolnok- Doboka-és Udvarhely vármegyébe vezényelt 1. hadsereg csendőr csoport-parancsnokságának az erőit koncentrálták. Cegléden, a Bihar vármegyébe vezényelt 2. hadsereg csendör csoport-parancsnokságának az eröit koncentrálták.

HIM.HL. Vezérkari fönökség 114/Föv.kat.közig. 40. IX. 2.

${ }^{26}$ Osztály-parancsnokságok: Beszterce, Csíkszereda, Dés, Kolozsvár, Máramarossziget, Marosvásárhely, Nagyvárad, Sepsiszentgyörgy, Szatmárnémeti, Székelyudvarhely, Zilah városokban, összesen 11 helyen. Szárny-parancsnokságok minden osztály állomáshelyén települtek, Nagyváradon kettő, Bánffyhunyad, Felsővisó, Gyergyószentmiklós, Gyergyótölgyes, Kézdivásárhely, Nagybánya, Nagykároly, Szamosújvár, Szászrégen, Székelykeresztúr, Szilágysomlyó és Naszód településeken. A polgári közigazgatás bevezetésekor a Gyergyótölgyesi és a Nagykárolyi szárny-parancsnokságok nem alakultak meg.

${ }^{27}$ Tájékoztató a kat.közig. müködéséről a felszabadult keleti és erdélyi részeken. op.cit.

${ }^{28}$ Segédlet a katonai közigazgatás és hadtáp ellátására Erdélyben.

${ }^{29}$ HIM.HL. BM.1940. 3200/Res. VI-b

${ }^{30}$ A románok Bánffyhunyadot, Naszódot és Nagyszalontát emelték városi rangra.

${ }^{31}$ HIM.HL. Vezérkari fönökség 120/Föv.kat.közig. elvei 40.IX.2.

${ }^{32}$ HIM.HL. Vezérkari fönökség. 60/Föv.kat.közig. 1940.

${ }^{33}$ Az I. magyar hadsereg csendőr csoport-parancsnoksága Marosvásárhelyre települt vitéz PAKSY-Kiss Tibor cső. alezds. parancsnokságával. A II. magyar hadsereg csendőr csoport-parancsnoksága Kolozsvárra települt PINTÉR Aladár cső. alezds. parancsnokságával. A III. magyar hadsereg csendőr csoport-parancsnoksága Nagybányára települt TöLGYESY Győző cső. alezds. Parancsnokságával. 1940. IX. 16. után az I. hadsereg-parancsnoksághoz beosztott csendőr csoport-parancsnokság tisztjei Marosvásárhelyről Kolozsvárra, míg a II hadsereg-parancsnoksághoz beosztott csendőr csoport tiszti állománya Kolozsvárról Marosvásárhelyre kölcsönös áthelyezést hajtottak végre. A III. hadsereg alárendeltségébe tartozó csendőr csoport-parancsnokság közvetlen szervezetei áttelepültek Szatmárnémetibe.

Vitéz PAKSY-KISS Tibor, PINTÉR Aladár és TÖLGYESY Győző csendőr tisztekről bővebbet ! SzAKÁLY: Akik a magyar királyi csendörséget 1919 és 1945 között vezették. Történelmi-statisztikai áttekintés a Magyar Királyi Csendörség felsö vezetéséröl. 180-181.p., 192.p. , 252.p.

${ }^{34}$ HIM.HL. Vezérkari fönökség. 1288/Föv.kat.közig. 40. IX. 30.

${ }^{35}$ HIM.HL. Vezérkari fönökség. 1318/Föv.kat.közig. 40. IX. 25.

${ }^{36}$ SzAKÁLY ! Akik a magyar királyi csendörséget 1919 és 1945 között vezették. Történelmi-statisztikai áttekintés a Magyar Királyi Csendörség felsö vezetéséröl. op.cit. 255-256.p.

${ }^{37}$ HIM.HL. Vezérkari fönökség. 1318/Föv.kat.közig. 40. IX. 25. op.cit.

${ }^{38}$ HIM.HL. HM. 1940. 76 904/eln.20.

${ }^{39}$ SZAKÁly: Akik a magyar királyi csendörséget 1919 és 1945 között vezették. Történelmi-statisztikai áttekintés a Magyar Királyi Csendörség felsö vezetéséröl. op.cit. 180-181.p.

${ }^{40}$ HIM.HL. BM. 1940. 3200/4.Res. VI-b.

41 Róla többet ! SZAKÁLY: Akik a magyar királyi csendőrséget 1919 és 1945 között vezették. Történelmi-statisztikai áttekintés a Magyar Királyi Csendörség felsö vezetéséröl. op.cit. 255-256.p. és 277.p. Észak-Erdély visszatérése nyomán létrehozott Kolozsvári IX. csendőr kerület parancsnokai voltak VATTAY Ferenc (1940. XI. 23. - 1942. VII. 31.), vitéz battyáni PAKSY-KISS Tibor [(1942. VII. 31. - 1942. VIII. 15.) - 1944.IX.15. (ténylegesen 1944.X.8.-ig)], lófő kibédi PÉTERFFY Jenő [1944.IX.15.- (ténylegesen 1944.X.8-tól) -1945].

${ }^{42}$ Róla többet ! SZAKÁLY: Akik a magyar királyi csendörséget 1919 és 1945 között vezették. Történelmi-statisztikai áttekintés a Magyar Királyi Csendörség felső vezetéséröl. op.cit. 192.p. és 277.p. Észak-Erdély visszatérése nyomán létrehozott Marosvásárhelyi X. csendőr kerület parancsnokai voltak PINTER Aladár (1944.XI.23. - 1942.XII.15.) dr. PAPP János (1942.XII.15. - 1944. IX. 7.)

${ }^{43}$ HIM.HL. BM.1924/Res. VI-b.-1941.sz. 
${ }^{44}$ SZAKÁLY: A magyar katonai felsö vezetés 1938-1945. Lexikon és adattár. 113-114.p.

45 SZAKÁLy: Akik a magyar királyi csendörséget 1919 és 1945 között vezették. Történelmi-statisztikai áttekintés a Magyar Királyi Csendörség felsö vezetéséröl. op.cit. 127-128.p.

${ }^{46}$ HIM.HL. HM.1941. 184.sz.kt./eln.20.

${ }^{47}$ Loc.cit.

${ }^{48}$ Ezek állomáshelyei: Horgos, Kelebia, Alsócsikéria, Turipuszta, Regőce, Béreg, Udvar, Lőcs és Torjánc voltak.

PARÁDI: A magyar állam határőrizete 1920-1941. op.cit. 191-207.p. ; PARÁDI: A Magyar Királyi Csendőrség. Az első magyar polgári, központositott, közbiztonsági örtestület 1881-1945. op.cit. 102-103.p. ; HIM.HL. HM.1941.457/Föv.kat.közig. IV.24.

${ }^{49}$ HIM.HL. HM.1941. 100 167/eln.20.

${ }^{50}$ Osztályparancsnokság: Zomborra és Újvidékre, szárnyparancsnokság: Muraszombatra, Szabadkára, Újvidéken, Zentára és Zomborra települt.

Jegyzetekben alkalmazott röviditések:

\section{MONOGRÁFIÁK, KISMONOGRÁFIÁK ÉS HASONLÓ JELLEGÜ KÖTETEK}

ADONYI-NÁREDY - NAGY

- AdONYI-NÁRedy Ferenc - NAGY Kálmán: Magyar huszárok a II. világháborúban. Sárvár-Szombathely, 1990, Huszár Múzeum Baráti Kör - Tikett Nyip. Kft. 144 p. HU-ISBN 963040501 6. /Huszártörténeti tanulmányok, 1./ HU-ISSN 0866-2592.

PARÁdi: A Magyar Királyi Csendörség. Az elsö magyar polgári, központositott, közbiztonsági örtestület 1881-1945.

PARÁDI: A Magyar Királyi Csendőrség. Az első magyar polgári, központositott, közbiztonsági örtestület 1881-1945. Budapest, 2012, Szemere Bertalan Magyar Rendvédelem-történeti Tudományos Társaság. 281 p. HU-ISBN 97896308 4794 0. /A magyar rendvédelem-történet öröksége, 2./ HU-ISSN 2062-8447.

KAISER: A Magyar Királyi Csendör- - KAISER Ferenc: A Magyar Királyi Csendörség története a két világháború ség története a két világháború között. között. Pécs, 2002, Pro Pannónia Kiadói Alapítvány. 175 p. HU-ISBN 96390 7982 0. /Pannónia Könyvek./ HU-ISSN 0237-4277.

SZAKÁlY: A magyar tábori csendörség története 1938-1945.

SZAKÁLy Sándor: A magyar tábori csendörség története 1938-1945. Budapest, 2000, Ister. 173 p. HU-ISBN 9639243248.

\section{TANULMÁNYOK}

OLASZ - PARÁDI - ZEIDLER

- Olasz György - PARÁdi József — Zeidler Sándor: A magyar állami rendvédelmi testületek katonai rendfokozati rendszerei a kiegyezéstől az ezredfordulóig. Rendvédelem-történeti Füzetek (Acta Historiae Praesidii Ordinis), XV.évf. (2008) 18.sz. 29-63.p. HU-ISSN 1216-6774. A tanulmány korábbi változata 2004. október 13-án Budapesten hangzott el a Szemere Bertalan Magyar Rendvédelem-történeti Tudományos Társaság által szervezett rendvédelem-történeti tudományos konferenciasorozatnak „Karhatalmi feladatok a bünmegelözés és a békefenntartás szolgálatában Európában a XIXXX. században" címü XVIII. konferenciáján. A publikált tanulmány az előadás javított, bővített és átdolgozott változata.

ZEIDLER

- ZEIDLER Sándor: A magyar rendőri rangok fejlődéstörténete a kiegyezéstől az ezredfordulóig. Rendvédelem-történeti Füzetek (Acta Historiae Praesidii Ordinis), XIV.évf. (2008) 17.sz. 116-137.p. HU-ISSN 1216-6774. A tanulmány korábbi változata 2003. november 11-én Budapesten hangzott el a Szemere Bertalan Magyar Rendvédelem-történeti Tudományos Társaság által szervezett rendvédelem-történeti tudományos konferenciasorozatnak „A rendvédelem humán viszonyai" című XVII. konferenciáján. A publikált tanulmány az előadás javított, bővített és átdolgozott változata.

\section{CIKKEK}

Magyar Csendörök a Felvidéken. I. rész.

- Magyar Csendörök a Felvidéken. (Szerkesztőségi közlemény) Csendőrségi Lapok, XXVIII.évf. (1938) 22.sz. 746-765.p. I.rész.

Magyar Csendőrök a Felvidéken. II. rész.

- Magyar Csendőrök a Felvidéken. (Szerkesztöségi közlemény) Csendörségi Lapok, XXVIII.évf. (1938) 23.sz. 787-790.p. II.rész.

Magyar Csendőrök a Felvidéken. — - Magyar Csendőrök a Felvidéken. (Szerkesztőségi közlemény) Csendőrségi III. rész. Lapok, XXVIII.évf. (1938) 24.sz. 830-835.p. III.rész.

BARTOS

- BARTOS Ödön: A híradó őrsök szolgálatáról. Csendörségi Lapok, XXX.évf. (1940) 2.sz. 34-38.p.

\section{LEVÉL-, IRAT- ÉS DOKUMENTUMTÁRAK}

HIM-HL — Hadtörténeti Intézet és Múzeum Hadtörténelmi Levéltára.

\section{KÉZIRATOK}

PARÁDI: A magyar állam határőrizete — PARÁDI József: A magyar állam határőrizete 1920-1941. Kandidátusi értekezés 1920-1941.

(MTA). Kézirat. Budapest, 1990. 


\section{LEXIKONOK, ADATTÁRAK}

SZAKÁLY: Akik a magyar királyi csendôrséget 1919 és 1945 között vezették. Történelmi-statisztikai áttekintés a magyar királyi csendőrség felsö vezetőiröl.

SZAKÁLY: A magyar katonai felsö vezetés 1938-1945. Lexikon és adattár.

\section{SZABÁLYZATOK}

Segédlet a katonai közigazgatás és hadtáp ellátására Erdélyben.

Tájékoztató a katonai közigazgatás. müködéséröl a felszabadult keleti és erdélyi részeken.

\section{JOGSZABÁLYOK}

1921/XXXIII.tc.
SZAKÁLY Sándor: Akik a magyar királyi csendörséget 1919 és 1945 között vezették. Történelmi-statisztikai áttekintés a magyar királyi csendörség felsö vezetőiröl. Budapest, 2013, Magyar Napló. 301 p. HU-ISBN 9789639961272.

- SzakÁly Sándor: A magyar katonai felső vezetés 1938-1945. Lexikon és adattár. Budapest, 2001, Ister. 409 p. HU-ISBN 963924337 X.

Segédlet a katonai közigazgatás és hadtáp ellátására Erdélyben. Dr. SuBA János magángyüjteményében.

— Tájékoztató a katonai közigazgatás müködéséröl a felszabadult keleti és erdélyi részeken. Dr. SuBA János magángyüjteményében.

- 1921/XXXIII.tc. az Észak-Amerikai Egyesült Államokkal, a Brit Birodalommal, Franciaországgal, Olaszországgal és Japánnal, továbbá Belgiummal, Kínával, Kubával, Görögországgal, Nikaraguával, Panamával, Lengyelországgal, Portugáliával, Romániával, a Szerb-Horvát-Szlovén Állammal, Sziámmal és Cseh-Szlovákországgal 1920. évi június hó 4. napján a Trianonban kötött békeszerződés becikkelyezéséről.

Mellékletek jegyzéke:

I.sz. melléklet

A Magyar Királyi Csendőrség szervezeti egységtípusonkénti elhelyezkedése 1938. májusában csendör kerületenként.

II.sz. melléklet

A Magyar Királyi Csendőrség szervezeti egységtípusainak elhelyezkedése 1939. februárjában kerületenként.

III.sz. melléklet

A trianoni határokon belül 1938.V.1. - 1939.II.1. között bekövetkezett elhelyezési változások.

IV.sz. melléklet

A katonai közigazgatások időszakai a visszatért területeken.

I.sz. melléklet

A Magyar Királyi Csendőrség szervezeti egységtípusonkénti elhelyezkedése 1938. májusában kerületenként.

\begin{tabular}{|l|c|c|c|c|c|c|}
\hline kerület pk.-ság. & $\begin{array}{c}\text { osztály } \\
\text { pk.-ság. }\end{array}$ & $\begin{array}{c}\text { szárny } \\
\text { pk.-ság. }\end{array}$ & $\begin{array}{c}\text { szakasz } \\
\text { pk.-ság. }\end{array}$ & $\begin{array}{c}\text { pk.-ság. } \\
\text { összesen }\end{array}$ & örs & különítmény \\
\hline I. Bp. & 4 & 12 & 28 & 44 & 119 & 7 \\
\hline II. Székesfehérvár & 4 & 11 & 28 & 43 & 117 & 8 \\
\hline III. Szombathely & 4 & 11 & 30 & 45 & 117 & 3 \\
\hline IV. Pécs & 3 & 10 & 26 & 39 & 112 & \\
\hline V. Szeged & 3 & 8 & 21 & 42 & 88 & 1 \\
\hline VI. Debrecen & 3 & 8 & 22 & 33 & 89 & 1 \\
\hline VII. Miskolc & 3 & 10 & 26 & 39 & 109 & 1 \\
\hline összesen & $\mathbf{2 4}$ & $\mathbf{8 0}$ & $\mathbf{1 8 1}$ & $\mathbf{2 8 5}$ & $\mathbf{7 5 1}$ & $\mathbf{2 1}$ \\
\hline
\end{tabular}

Jelmagyarázat: $\quad$ pk.-ság. $=$ parancsnokság

Forrás ! Csendőrségi Zsebkönyv, XLVII.évf. (1939) Budapest, Stádium. 376 p.

II.sz. melléklet

A Magyar Királyi Csendörség szervezeti egységtípusainak elhelyezkedése 1939. februárjában kerületenként.

\begin{tabular}{|l|c|c|c|c|c|}
\hline \multicolumn{1}{|c|}{ kerület pk.-ság. } & $\begin{array}{c}\text { osztály } \\
\text { pk.-ság. }\end{array}$ & $\begin{array}{c}\text { szárny } \\
\text { pk.-ság. }\end{array}$ & $\begin{array}{c}\text { szakasz } \\
\text { pk.-ság. }\end{array}$ & $\begin{array}{c}\text { pk.-ság. } \\
\text { összesen }\end{array}$ & örs \\
\hline I. Budapest & 3 & 9 & 25 & 37 & 87 \\
\hline II. Székesfehérvár & 4 & 13 & 36 & 53 & 128 \\
\hline III. Szombathely & 4 & 10 & 30 & 44 & 100 \\
\hline IV. Pécs & 4 & 12 & 39 & 55 & 131 \\
\hline V. Szeged & 4 & 8 & 28 & 40 & 93 \\
\hline VI. Debrecen & 4 & 9 & 26 & 39 & 95 \\
\hline VII. Miskolc & 4 & 12 & 37 & 53 & 124 \\
\hline VIII. Kassa & 5 & 13 & 35 & 53 & 121 \\
\hline összesen & $\mathbf{3 2}$ & $\mathbf{8 6}$ & $\mathbf{2 5 6}$ & $\mathbf{3 7 4}$ & $\mathbf{8 7 9}$ \\
\hline
\end{tabular}

Jelmagyarázat: pk.-ság. = parancsnokság

Forrás ! Csendőrségi Zsebkönyv, XLVIII.évf. (1940) Budapest, Stádium. 426 p. 
A trianoni határokon belül 1938.V.1. - 1939.II.1. között bekövetkezett elhelyezési változások.

\begin{tabular}{|c|c|c|c|c|c|c|}
\hline & & \multicolumn{2}{|c|}{ megszünt } & & \multicolumn{2}{|c|}{ felállt } \\
\hline \multirow{8}{*}{ I. ker.pk.-ság } & 1 & \multicolumn{2}{|c|}{ I. ö. lov.alo. } & 1 & Lakihegy & örs \\
\hline & 2 & Lakihegy & kül. & 2 & Pilismarót & örs \\
\hline & 3 & Leányfalu & örs & 3 & Solymár & örs \\
\hline & 4 & Pilismarót & kül. & 4 & Törökbálint 2. & örs \\
\hline & 5 & Solymár & kül. & 5 & Törtel & örs \\
\hline & 6 & Törökbálint-gyártelep & kül. & 6 & Zagyvaróna & örs \\
\hline & 7 & Törtel & kül. & & & \\
\hline & 8 & Zagyvaróna-Vizválasztó & kül. & & & \\
\hline \multirow{16}{*}{ II. ker.pk.-ság } & 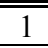 & \multicolumn{2}{|c|}{$\begin{array}{l}\text { II. ö. lov.alo. } \\
\end{array}$} & 1 & Csolnok & örs \\
\hline & 2 & Csolnok-Augusztatelep & örs & 2 & Dorog & örs \\
\hline & 3 & Dorog-bányaújtelep & örs & 3 & Dunaalmás & örs \\
\hline & 4 & Dunaalmás & kül. & 4 & Esztergom & oszt. \\
\hline & 5 & Ilkamajor & kül. & 5 & Ilkamajor & örs \\
\hline & 6 & Inota & kül. & 6 & Inota & örs \\
\hline & 7 & Lajoskomárom & örs & 7 & Mesterháza & örs \\
\hline & 8 & Mesterháza & kül. & 8 & Mezőkomárom & örs \\
\hline & 9 & Pét-gyártelep & kül. & 9 & Pét-gyártelep & örs \\
\hline & 10 & Szfvár-rádióállomás & kül. & 10 & Szvár-rádiótelep & örs \\
\hline & 11 & Szomor & & 11 & Szomor & örs \\
\hline & 12 & Tárnok & & 12 & Tárnok & örs \\
\hline & 13 & Tata & szárny & 13 & Tatatóváros & Sz. \\
\hline & 14 & Tata & gy.tan.alo. & 14 & Tatatóváros & gy.tan.alo. \\
\hline & 15 & Tokod-Altáró & \begin{tabular}{|l|} 
örs \\
\end{tabular} & 15 & Tatatóváros & örs \\
\hline & 16 & Tóváros & örs & 16 & Tokod & örs \\
\hline \multirow{8}{*}{ III. ker.pk.-ság } & 1 & \multicolumn{2}{|c|}{ III. ö. lov.alo. } & 1 & "Balatonzamárdi & örs \\
\hline & 2 & Balatonzamárdi & kül. & 2 & Bősárkány & örs \\
\hline & 3 & Cséppuszta & örs & 3 & Felsőbagod & örs \\
\hline & 4 & Felsőbagod & kül. & 4 & Ikervár & örs \\
\hline & 5 & Ikervár & kül. & 5 & Jánosháza & közl.örs \\
\hline & 6 & Veszprém & szárny & 6 & Szombathely & 3.szd. \\
\hline & & & & 7 & Veszprém 1. & \begin{tabular}{|l|} 
Sz. \\
\end{tabular} \\
\hline & & & & 8 & Veszprém 2. & sz. \\
\hline IV ker.pk.-ság & 1 & IV. ö. lov. & & 1 & Dunaföldvár & közl.őrs \\
\hline \multirow{4}{*}{ V. ker. pk.-ság } & 1 & \multicolumn{2}{|c|}{ V. ö. lov.alo. } & 1 & Baja & oszt. \\
\hline & 2 & Köröstarcsa & kül. & 2 & Köröstarcsa & örs \\
\hline & & & & 3 & Szeged & oszt. \\
\hline & & & & 4 & Szolnok & közl.őrs \\
\hline \multirow{6}{*}{ VI. ker. pk.-ság } & 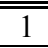 & \multicolumn{2}{|c|}{ "VI. ö. lov.alo. } & 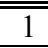 & "Berettyóújfalu & \begin{tabular}{|l} 
oszt. \\
\end{tabular} \\
\hline & 2 & Nagycsere & kül. & 2 & Debrecen & közl.őrs \\
\hline & 3 & Nagyhortobágy & örs & 3 & Hortobágy & örs \\
\hline & 4 & Nyíregyháza & szárny & 4 & Nagycsere & örs \\
\hline & & & & 5 & Nyíregyháza 1. & sz. \\
\hline & & & & 6 & Nyíregyháza 2. & sz. \\
\hline \multirow{4}{*}{ VI. ker. pk.-ság } & 1 & \multicolumn{2}{|c|}{ VII. ö. lov.alo. } & 1 & Miskolc & közl.örs \\
\hline & 2 & Sátoraljaújhely & sz. & 2 & Sátoraljaújhelyl & sz. \\
\hline & 3 & Visonta & kül. & 3 & Sátoraljaújhely2 & sz. \\
\hline & & & & 4 & Visonta & örs \\
\hline
\end{tabular}

Jelmagyarázat: alo. $=$ alosztály ; gy. $=$ gyalog ; közl. $=$ közlekedési $;$ kül. $=$ különítmény ; oszt. $=$ osztály ; pk.-ság. $=$ parancsnokság ; sz. = szakasz ; szd. = század ; tan. = tanulmányi

Forrás ! Csendörségi Zsebkönyv, XLVII.évf. (1939) Budapest, Stádium. 376 p. ; Csendörségi Zsebkönyv, XLVIII.évf. (1940) Budapest, Stádium. 426 p. 
IV.sz. melléklet

A katonai közigazgatások idöszakai a visszatért területeken.

\begin{tabular}{|c|c|c|c|}
\hline \multirow[t]{2}{*}{ S.sz. } & \multirow[t]{2}{*}{ Terület } & \multicolumn{2}{|c|}{ Katonai közigazgatás } \\
\hline & & kezdete & vége \\
\hline 1 & Felvidék déli sávja & 1938. XI. 5. & 1939. I. 5. \\
\hline 2 & Kárpátalja & 1939. III. 17. & 1939. VII. 7. \\
\hline 3 & Észak-Partium és Észak-Erdély & 1940. IX. 4. & 1940. XI. 23. \\
\hline 4 & $\begin{array}{l}\text { Délvidék részlegesen } \\
\text { a Drávaszöggel és Muraközzel }\end{array}$ & 1941. IV. 14. & 1941. V. 5. \\
\hline
\end{tabular}

